\title{
Characterization of Chromosomal Abnormalities in Cancer by Spectral Karyotyping
}

\author{
Sharafudeen Dahiru Abubakar \\ Ahmadu Bello University, Zaria, \\ Nigeria \\ Corresponding author: Sharafudeen \\ Dahiru Abubakar \\ Email: dsabubakar@abu.edu.ng \\ Tel: $+81-8088823577$ \\ Address: Ahmadu Bello University, \\ Zaria, Nigeria \\ Received: 27 Jul 2019 \\ Revised: 01 Aug 2019 \\ Accepted: 08 Aug 2019 \\ (c) (i) (8) \\ This work is licensed under a Creative \\ Commons Attribution 4.0 License.
}

\begin{abstract}
Spectral karyotyping is a novel method for the simultaneous visualization of the entire chromosomes of an organism by painting the chromosomes using a combination of fluorochromes. This allows improved identification of chromosomal aberrations that cannot be identified by conventional banding methods. Since introduction of cancer as a disease of the genome, researchers have employed various molecular techniques for a better understanding of malignancies. This review discusses the role and contributions of spectral karyotyping in the study and characterization of both solid and hematological malignancies.

Keywords: Spectral karyotyping; Neoplasms; Chromosomes.
\end{abstract}

This paper should be cited as: Dahiru Abubakar SH[Characterization of Chromosomal Abnormalities in Cancer by Spectral Karyotyping]. mljgoums. 2019; 13(6): 1-10 


\section{INTRODUCTION}

The first report of human chromosomes was made in 1882 by Flemming, in which 2228 chromosomes in the dividing cells of the corneal epithelium were described (1). In 1922, Painter reported that the number of human chromosomes was 48 and that sex was determined according to the presence or absence of the Y chromosome (1). The report of " $2 n=46$ " made in 1956 by Tjio and Levan established the nature of human chromosomes (1). Following this report, the relationships between various congenital disorders and chromosomal abnormalities were being revealed one after another (2). In 1959, Lejeune et al. (3) demonstrated that Down syndrome is caused by the presence of an extra chromosome 21 , i.e., trisomy (4). This was a turning point in the subsequent discovery of other trisomy syndromes, including chromosomes $18(5,6), 13(7), 8$ (8), and 22 $(9,10)$. Besides the chromosomal number aberrations, abnormalities associated with sex chromosomes, such as Turner syndrome (11), Klinefelter syndrome (12) and other chromosomes $(6,13)$ were reported.

Several techniques have been developed for the identification and study of chromosomes. In 1971, Caspersson et al. developed Qstaining using quinacrine mustard, a fluorescent dye that binds to DNA, which was instrumental in the discovery that chromosomes have banding patterns (stripes) (14). Later, improved staining techniques, including $\mathrm{R}-, \mathrm{T}-, \mathrm{C}-$, and G-staining, were developed (2). The analysis of bands has further advanced into high-resolution chromosome banding (15). Later, the development of fluorescent in situ hybridization technique (FISH) enabled detection of chromosomal microdeletions and structural abnormalities (16). More recent FISH-based techniques such as comparative genomic hybridization (17) and spectral karyotyping (SKY) (18) have relatively improved chromosomal analysis capability.

Theodor Boveri projected that cancer is caused by chromosomal derangements that cause cells to divide uncontrollably (19); in modern terms, cancer is a "disease of the genome". Researchers have established two main types of cancer-causing genes (oncogenes and tumor suppressor genes) and the genomic alterations that give rise to them (e.g., nucleotide substitutions, chromosomal copy number alterations, and DNA rearrangements) (20). These studies also began to suggest considerable complexity in the mutational origins of cancer, with cancer-causing genes varying across and within tumor types and with multiple genes contributing to tumorigenesis (21).

An increased understanding of malignancies and the advent of improved cell culture techniques led to the discovery of the Philadelphia chromosome, a chromosomal abnormality specific to chronic myelogenous leukemia (22). Subsequently, mutations were discovered in melanoma (23), colon (24) and lung cancer (25). The US National Cancer Institute launched the Cancer Genome Atlas (TCGA) in 2009; concordantly, an International Cancer Genome Consortium was established with contributions from researchers from over 15 countries (26).

\section{Principle of SKY}

Two techniques are used as the basic principles of FISH: chromosome painting and multicolor fluorescence. The former involves drawing an entire image of certain chromosomes using fluorescent signals, while the latter involves drawing images of several hybridization signals with different florescent dyes. In 1996, Schrock et al. developed the SKY technique by combining these two techniques (18).

In SKY, the color emission of chromosomes is determined by combining painting probes and fluorescent dyes. In this technique, new colors can be developed by extracting a pair of different fluorescent dyes from the five fluorescent dyes used in this technique including Spectrum Orange, Texas Red, Cy5, Spectrum Green and Cy5.5, and mixing each pair together. Thus, it is theoretically possible to create $2^{\mathrm{n}}-1$ number of colors from $\mathrm{n}$ types of fluorescent dyes. Therefore, 31 color types can be created from five types of fluorescent dyes (Figure 1). In reality, however, because some fluorescence has a wavelength close to that within the infrared spectrum, a twodimensional imaging spectroscopy system (e.g., the Spectral Bio-Imaging System SD200, Applied Spectral Imaging Ltd. Israel) needs to be used to process spectral images so that 24 macroscopically distinguishable colors can be created (2). The amount of samples required for chromosome testing for regular congenital abnormalities is about $3.0 \mathrm{ml}$ of 
heparin-treated blood and about $1.0 \mathrm{ml}$ of bone marrow fluid and about $5.0 \mathrm{ml}$ of blood in the case of blood disorders. Currently, no standardized method is available for describing chromosome karyotypes based on SKY analysis (2).

\section{Overview of methodology of SKY}

SKY involves various steps as outlined by Trakhtenbrot (28):

1. A probe cocktail (Applied Spectral Imaging Ltd, Migdal, Israel) consisting of fluorescently labeled probes for each chromosome is made by labeling chromosome specific libraries generated by PCR from flow-sorted chromosomes with specific combinations of one or more of the five spectrally distinct fluorochromes (FITC, Rhodamine, Texas Red, Cy5 and Cy5.5).

2. Metaphase preparations are hybridized with this probe cocktail and then stained with 4,6diamidino-2 phenylindole (DAPI) in antifade medium.

3. The SpectraCube ${ }^{\circledR}$ Imaging system (Applied Spectral Imaging Ltd, Migdal Ha'emeg, Israel) as shown in Figure 2 is used to discriminate between the different spectral characteristics of chromosomes. The system measures chromosome-specific emission spectra generated by the combinatorially labeled chromosome-specific painting probes.

4. The spectral signature of the fluorochrome combinations is analyzed using SKYVIEWTM software, which classifies the chromosomes by comparing the acquired spectral characteristics to the combinatorial library containing the fluorochrome combinations for each chromosome. In the classified image, the chromosomes appear in a Red-Green-Blue (RGB) display in which FITC is seen as blue, Rhodamine and Texas Red are seen as different shades of green and the infrared dyes not visible to the human eye, Cy5 and Cy5.5, are assigned different shades of red.

5. The chromosomes are then automatically sorted into a karyotype table according to the nomenclature rules for G-bands. Rearrangements, translocations between different chromosomes and components of marker chromosomes are all easily identified because of a color change at the point of transition. Finally, the software assigns a specific classification pseudo-color to each chromosome allowing chromosomal aberrations to be even more easily visualized.
6. The DAPI image is captured separately and inverted to give a G-banding-like pattern (Figure 3). This image may be used to compliment the SKY analysis with chromosome banding information.

\section{Applications of SKY}

SKY has proven valuable in clinical cytogenetics for identifying chromosomal rearrangements that cannot be recognized by conventional G-banding, such as translocations that either are subtle or involve regions with similar banding patterns. Analysis of complex chromosomal re-arrangements in solid tumor cytogenetics has also been accomplished as well as identifying de novo balanced and unbalanced translocations, which are occasionally quite small and difficult to identify. Identification of inter-chromosomal aberrations has been a major application of this technique that has a great potential use in comparative cytogenetics. Another application of SKY extends to the multiparameter analysis of cytological preparations (2,18,27-29).

SKY analysis has revealed numerous markers and derivate chromosomes, hidden translocations, chromosomal insertions, homogeneous staining regions and double minutes unidentified or incorrectly identified by G-banding (28). Due to the nature of painting probes, SKY alone cannot detect intra-chromosomal rearrangements, such as paracentric or pericentric inversions, small duplications and deletions. The resolution of SKY (1-3 Mb) depends on the level of chromosomal condensation and on the combination of the fluorochromes involved in structural rearrangements. Thus, SKY should be seen as a complement rather than a replacement of conventional G-banding analysis (28).

\section{Cancer characterization by SKY}

SKY is particularly valuable in cancer cytogenetics and provides a much more detailed portrayal of the highly abnormal karyotypes that characterize advanced tumors and cancer cell lines. The detailed definition of markers by the SKY technique leads to the determination of an increased number of aberrations per tumor, identification of more chromosomal regions involved in the karyotype evolution and the analysis of more metaphases, especially polyploid. SKY also enables the discovery of a larger number of sub-clones and the revelation of different 
clonal evolution pathways of karyotype alterations in cancer $(28,29)$.

Table 1 shows a chronological outline of findings related to chromosomal aberrations identified using SKY with or without the augmentation of other molecular techniques.

Comparisons, Capabilities And Limitatons Of Spectral Karyotyping

SKY is a FISH-adapted protocol that can be used to detect both chromosome copy number changes as well as gross translocations within the entire genome $(2,74)$.

For FISH, Multiplex FISH (M-FISH), Combined Ratio-FISH (COBRA-FISH) and Spectral Karyotyping (SKY), metaphase chromosome spreads are required [75]. Instead of one labelled probe per chromosome, SKY employs chromosome-specific probe sets consisting of up to five distinct fluorescent dyes, resulting in chromosome-specific, unique combinations (75). This allows for simple detection of all chromosomes in a metaphase spread. Another main difference between FISH-based methods and SKY is the detection method of the labelled chromosomes: a fluorescence microscope for FISH-based methods and an interferometer for SKY [76].

The key limitation for SKY is the requirement of dividing cells (34). In some cases, dividing cells are not available, e.g. in the case of paraffin-embedded material or primary tumor material. Furthermore, when harvesting primary tumor material, colcemid-mediated enrichment of mitotic cells to obtain condensed chromosomes is not possible, which, together with low proliferation rates, disqualifies metaphase-dependent aneuploid-quantification (34).

Figure 1- The spectra measured for the five chromosomes. The spectra shown are normalized by dividing each spectrum by the transmission spectrum (of the emission band) of the triple-bandpass filter (27)

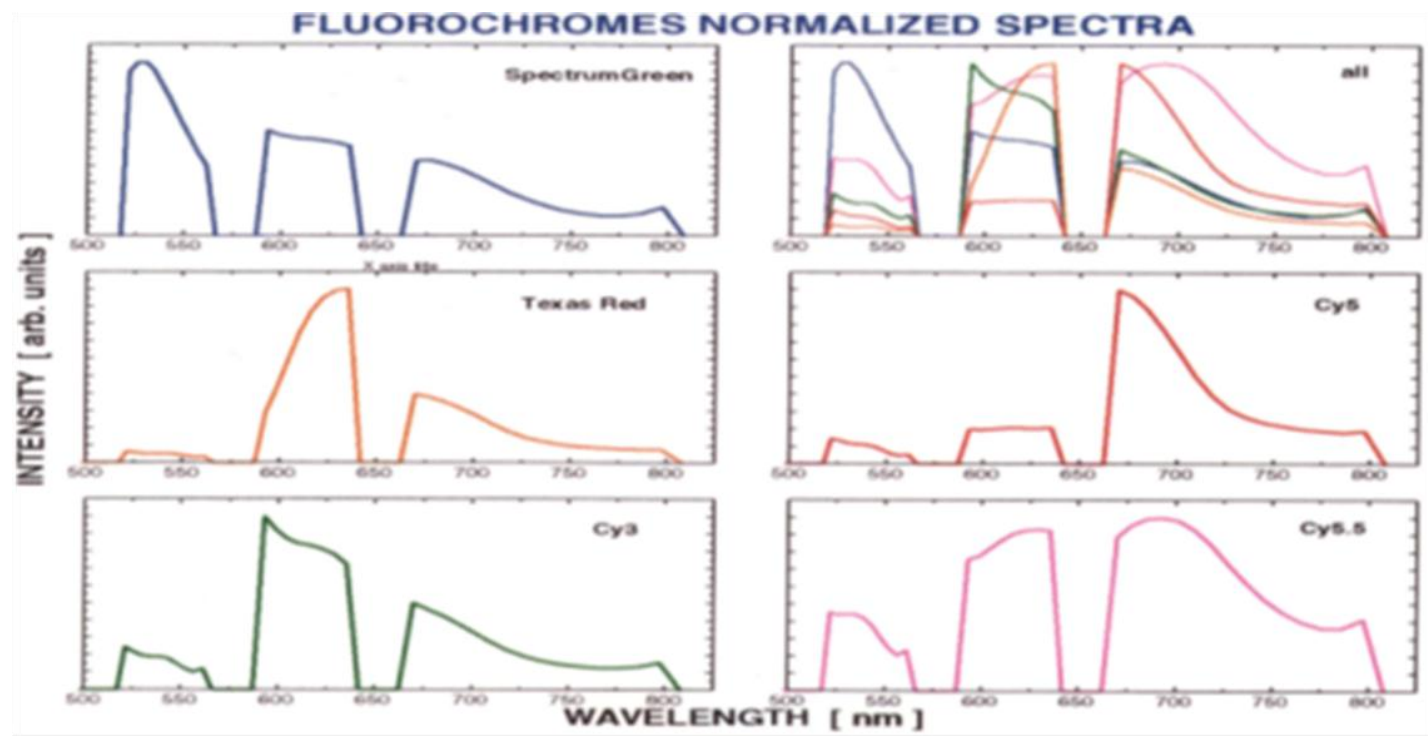


Another important challenge of SKY is the detection of intrachromosomal arrangements (63). This has been remedied with the introduction of multiplex multicoloured banding $(\mathrm{mMCB})$ and spectral color banding (SCAN) (77). These techniques improve on the advantages of COBRA-FISH, M-FISH and SKY allowing simultaneous visualization of chromosome bands in different colors in a single hybridization.
Other challenges associated with the technique include the need for quality mitoses, a successful hybridization and the high cost (27). The cost might be remedied by reducing the amount of fluorochromes used or perhaps expedient another labeling technique that involves cheaper chemicals. Automation of the technique might be helpful as well as miniaturization of the equipment needed.

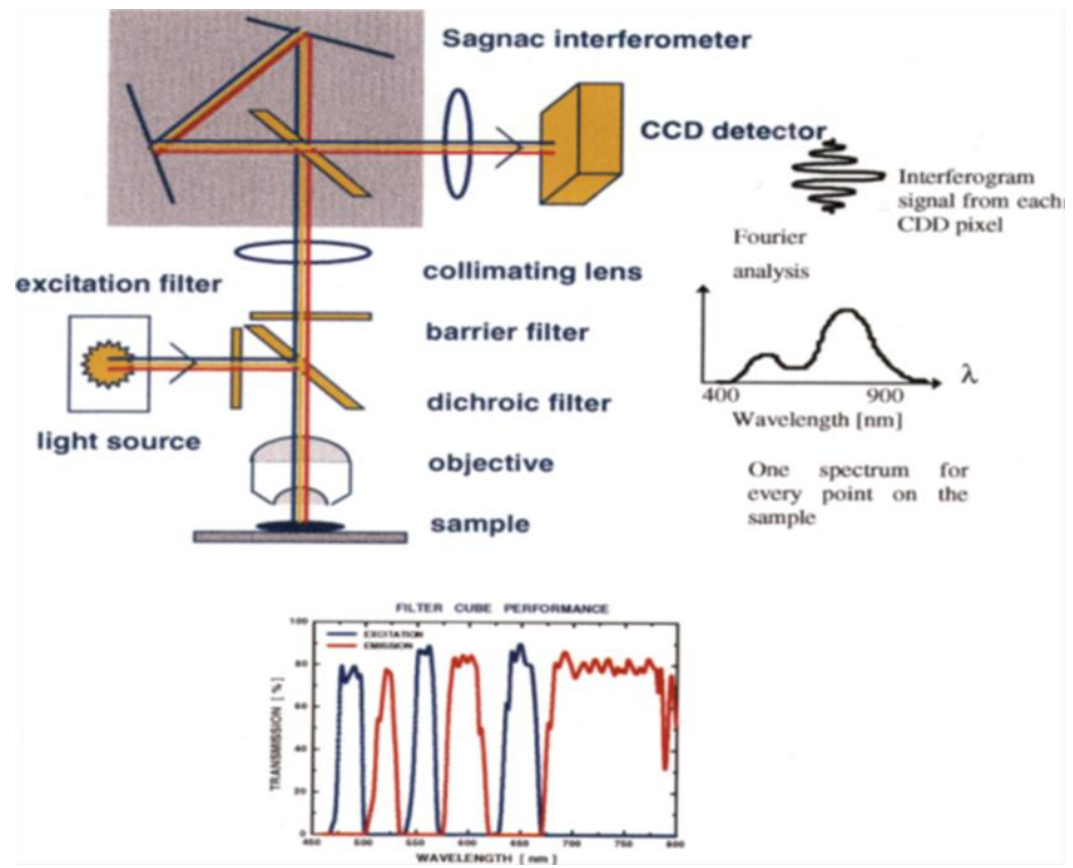

Figure 3- Illustration of karvotvpes as displaved bv SKY (27)

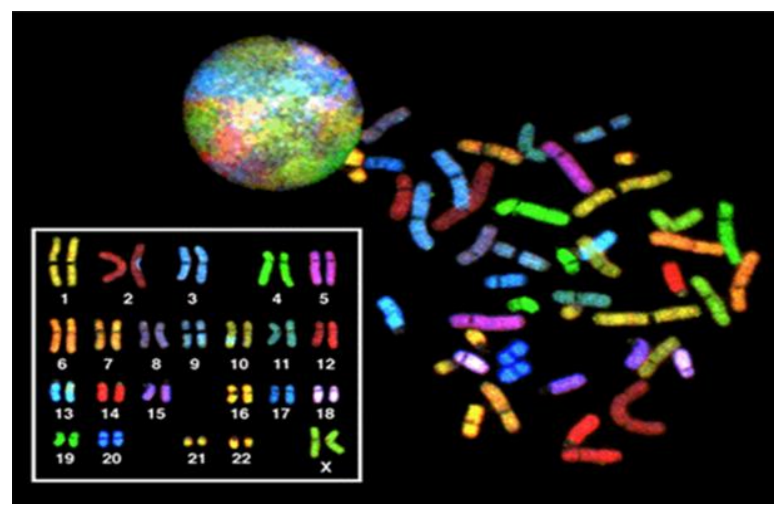


Table 1-Chromosomal characterization of cancer using SKY

\begin{tabular}{|c|c|c|c|}
\hline Cancer type / cell line & Chromosome(s) affected & Type of aberration & Additional notes \\
\hline HeLa cell line (30) & $\begin{array}{c}1,2,3,5,2,8,9,11,12,13,15,16,19,20 \\
22\end{array}$ & Chromosomal breakpoints & Identification of 2 sub-clones \\
\hline Prostate cancer cell lines (31) & $1,2,4,6,10,15,16$ & $\begin{array}{c}\text { Balanced translocations and pinpoint } \\
\text { rearrangements }\end{array}$ & New alterations identified \\
\hline Acute myeloid leukemia (32) & $7,11,23$ & $\begin{array}{l}\text { Cryptic 11q } 23 \text { translocation in } 20 / 20 \text { cells and a } \\
\text { minor monosomy } 7 \text { clone in } 3 / 21 \text { cells }\end{array}$ & $\begin{array}{l}\text { Previously diagnosed as } \\
\text { cytogenetically normal }\end{array}$ \\
\hline Colon cancer cell lines (33) & $2,5,7,8,12,11,13,14,18,20,22$ & Complex rearrangements & $\begin{array}{l}\text { Redefinition of } 6 \text { markers and } 13 \\
\text { newly identified markers }\end{array}$ \\
\hline Breast carcinoma cell lines (34) & $1,4,8,10,11,14,17$ & Unbalanced Translocations & $\begin{array}{l}\text { Chromosome } 8 \text { was predominantly } \\
\text { affected in } 19 \text { cell lines }\end{array}$ \\
\hline Breast cancer cell lines (35) & $1,7,8,9,11,13,16,17,18,20$ & Unbalanced translocations & $\begin{array}{l}\text { Major translocations in } 15 \text { cancer } \\
\text { cell lines were outlined with } \\
\text { chromosome } 8 \text { being the most } \\
\text { frequently affected }\end{array}$ \\
\hline $\begin{array}{l}\text { Medulloblastoma and related primitive } \\
\text { neuroectodermal tumours (36) }\end{array}$ & $3,6,7,10,13,14,17,18,22$ & Aneusomy & $\begin{array}{l}\text { Chromosome } 7 \text { and } 17 \text { are the most } \\
\text { commonly affected }\end{array}$ \\
\hline Non-Hodgkin’s lymphoma (37) & All chromosomes & Translocations & $\begin{array}{l}21 \text { previously unidentified } \\
\text { chromosomal rearrangements were } \\
\text { discovered }\end{array}$ \\
\hline $\begin{array}{c}\text { Primary breast carcinoma and their lymph } \\
\text { node metastasis ( } 38 \text { ) }\end{array}$ & $1,2,3,6,7,13,14,16,19,20,21,22, X$ & Complex translocations & $\begin{array}{l}\text { Similarities were noted in the } \\
\text { karyotype of primary cancers and } \\
\text { their metastatic tumors. }\end{array}$ \\
\hline Uroepithelial carcinoma (39) & $1,4,5,8,9,11,17$ & Several deletions & $\begin{array}{l}\text { Chromosome } 5 \text { rearrangement is } \\
\text { associated with more aggressive } \\
\text { phenotypes }\end{array}$ \\
\hline Multiple myeloma (40) & $8,14,11$ & Several translocations & $\begin{array}{l}\text { Translocation has been seen to } \\
\text { involve the whole arm of } 8 p\end{array}$ \\
\hline Breast cancer cell lines (41) & $8,11,12,21,22,23$ & Several translocations & $\begin{array}{l}\text { Chromosome } 8 \text { abnormal in } \\
\text { majority of them with chromosome } \\
11 \text { being the most frequent partner } \\
\text { in } 16 \text { cell lines }\end{array}$ \\
\hline Prostate cancer cell lines (42) & 8 & Aneusomy & $\begin{array}{l}\text { Evidence of chromosomal instability } \\
\text { in prostate cancer }\end{array}$ \\
\hline Colorectal cancer (43) & All autosomes & Structural abnormalities & $\begin{array}{l}\text { Additional subsets of colorectal } \\
\text { cancer revealed }\end{array}$ \\
\hline Pancreatic cancer cell lines (44) & $1,5,7,9,11,12,18$ & Unbalanced structural aberrations & $\begin{array}{l}\text { Loss at 11p and gains at } 5 p \text { and } 12 p \\
\text { are the most common }\end{array}$ \\
\hline Bladder cancer cell lines (45) & $8,12, X$ & Translocation and deletions & $\begin{array}{l}\text { Identification of RhoGDI2, a } \\
\text { candidate gene for bladder cancer }\end{array}$ \\
\hline $\begin{array}{l}\text { Epithelial cancer cell lines (ovarian and } \\
\text { colorectal cancer) (46) }\end{array}$ & $1,3,7,11,15,17,18$ & Numerical and structural abnormalities & $\begin{array}{l}\text { Obtaining a karyotype despite high } \\
\text { rates of chromosomal instability }\end{array}$ \\
\hline Acute myeloid leukemia (47) & $11,21,22$ & Structural aberrations & $\begin{array}{l}\text { Re-interpretation of acute myeloid } \\
\text { leukemia genome previously } \\
\text { discovered }\end{array}$ \\
\hline Head and neck squamous cell carcinoma (48) & $3,5,6,7,8,11,13,14,15,18,22,23$ & Structural aberrations & $\begin{array}{l}\text { Genetic changes in these } \\
\text { malignancies were identified }\end{array}$ \\
\hline Serous ovarian adenocarcinoma (49) & $1,2,3,4,6,8,9,10,11,12,17,18,20,21$ & $\begin{array}{l}\text { Unbalanced translocations, isochrmosomes and } \\
\text { deletions }\end{array}$ & $\begin{array}{l}\text { Loss of } 12 p 11.2 \text { common and } \\
\text { scattered in several chromosomes }\end{array}$ \\
\hline Nasopharyngeal carcinoma (50) & $2,3,5,6,7,8$ & Unbalanced and reciprocal translocations & $\begin{array}{l}\text { Chromosome } 2 \text { was the most } \\
\text { predominantly affected }\end{array}$ \\
\hline Osteosarcoma (51) & $8,17,20$ & Numerical and structural abnormalities & $\begin{array}{l}\text { Chromosome } 20 \text { is the most } \\
\text { frequently affected }\end{array}$ \\
\hline Cervical cancer cell lines (52) & All autosomes & Structural abnormalities & $\begin{array}{l}\text { Derivative chromosomes denoting } \\
\text { HPV sequences revealed }\end{array}$ \\
\hline Lung cancer cell lines (53) & $1,3,6,10,12,17,21,24$ & Unbalanced translocations & $\begin{array}{l}\text { Genomic characterization of } 10 \text { cell } \\
\text { lines }\end{array}$ \\
\hline Meningioma (54) & 22,23 & $\begin{array}{l}\text { Duplication, deletion and translocation of } \\
\text { chromosome } 22\end{array}$ & $\begin{array}{l}\text { Chromosome } 22 \text { abnormality was } \\
\text { the hallmark of the tumor }\end{array}$ \\
\hline Gastric cancer (55) & $1,3,7,8,11,13,1,20$ & Unbalanced translocations & $\begin{array}{l}\text { Chromosome } 8 \text { is the most } \\
\text { commonly affected }\end{array}$ \\
\hline Burkitt's lymphoma-derived B cell line (56) & $3,8,13,14,17$ & Translocations & $\begin{array}{l}\text { Novel rearrangements discovered } \\
\text { besides } t(8: 14)\end{array}$ \\
\hline Oral squamous cell carcinoma cell lines (57) & $1,3,5,8,10,11,16, X$ & Isochromosomes and derivative chromosomes & $\begin{array}{l}11 \text { p13 was the most commonly } \\
\text { affected site }\end{array}$ \\
\hline Virus infected cells (58) & All & Structural and numerical aberrations & $\begin{array}{l}\text { Evidence that viruses causes cancer } \\
\text { by inducing massive chromosomal } \\
\text { instability }\end{array}$ \\
\hline Colorectal cancer cell lines (59) & All & Translocation, deletion and uniparental disomy & $\begin{array}{l}\text { Uniparental disomy identified as an } \\
\text { early mutational event }\end{array}$ \\
\hline Lung cancer (60) & $1,2,3,5,6,9,11,12,13$ & Numeral and structural abnormalities & $\begin{array}{l}\text { Identifying chromosomal } \\
\text { aberrations leading to lung } \\
\text { carcinogenesis by studying smokers } \\
\text { with and without lung cancer }\end{array}$ \\
\hline Small cell lung cancer cell lines (61) & $3,5,16,18$ & Derivative chromosomes & $\begin{array}{l}\text { Long arm of chromosome } 18 \text { shows } \\
\text { potential for a marker of SCLC }\end{array}$ \\
\hline Various cancer cell lines (62) & The whole genome & $\begin{array}{l}\text { Multiple catastrophic breakpoints with several } \\
\text { structural aberrations }\end{array}$ & $\begin{array}{l}\text { The term "chromothripsis" was } \\
\text { coined to describe the massive } \\
\text { breakpoints and its rearrangement } \\
\text { in cancer development }\end{array}$ \\
\hline Urothelial cancer (63) & 5,9 & Deletions and rearrangements & Detection of p53 isoforms \\
\hline Colon cancer (64) & 8 & Structural abnormalities & $\begin{array}{c}\text { Discovery of CCAT2, a novel } \\
\text { noncoding RNA mapping to 8q24 }\end{array}$ \\
\hline Gastric cancer (65) & $10,12,17$ & $\begin{array}{l}\text { Structural rearrangements especially } \\
\text { amplification of some genes }\end{array}$ & $\begin{array}{l}\text { Identification of mutually amplified } \\
\text { FGFR2, HER2, and KRAS }\end{array}$ \\
\hline Lung cancer (66) & $1,3,5,8,11$ & Numerous structural abnormalities & $\begin{array}{l}\text { Chromosome } 8 \text { had the most } \\
\text { frequent alterations. }\end{array}$ \\
\hline Pancreatic cancer cell Lines (67) & $1,2,3,4,6,7,8,12,16,17,18$ & Structural abnormalities & $\begin{array}{l}\text { Discovery of novel PLXNA1 } \\
\text { mutation in chromosome } 3 \text { and } \\
\text { development of } 3 \text { novel cell lines }\end{array}$ \\
\hline $\begin{array}{l}\text { Head and neck squamous cell carcinoma cell } \\
\text { lines }(68)\end{array}$ & $1,2,3,7,8,11,14$ & Complex structural amplifications & $\begin{array}{l}\text { Chromosomes 1, } 7 \text { and } 11 \text { were the } \\
\text { most frequently affected }\end{array}$ \\
\hline Colorectal cancer (69) & All & Structural abnormalities & $\begin{array}{l}\text { Identification of MIIP gene in } \\
\text { Chromosome } 1 \text { as a novel potential } \\
\text { tumor suppressor }\end{array}$ \\
\hline Small cell lung cancer (70) & $5,18,20,22$ & Structural abnormalities & $\begin{array}{l}\text { Identification of unique genomic } \\
\text { regions }\end{array}$ \\
\hline Colorectal cancer cell lines (71) & All & Structural abnormalities & $\begin{array}{l}\text { Profound differences in genes of } \\
\text { various cell lines demonstrating the } \\
\text { diversity of clonal evolution }\end{array}$ \\
\hline HepG2 cell lines (72) & $2,6,16,17$ & Structural abnormalities & $\begin{array}{l}\text { Identification of the genomic } \\
\text { complexity of the cancer cell line }\end{array}$ \\
\hline Acute myeloid leukemia (73) & $5,7,17$ & Structural abnormalities & $\begin{array}{c}\text { Identification of different complex } \\
\text { genomes in typical and atypical } \\
\text { subtypes } \\
\end{array}$ \\
\hline
\end{tabular}


RhoGDI2: Rho GDP Dissociation Inhibitor 2, HPV: Human papilloma virus, SCLC: Small cell lung cancer, CCAT2: Colon cancer associated transcript 2, FGFR2: Fibroblast growth factor receptor 2, HER2: Human epidermal growth factor receptor 2, PLXNA1: Gene that codes for plexin-A1, MIIP: Migration and invasion inhibitory protein.

\section{CONCLUSION}

Since the discovery of SKY by Schrock et al. in 1996, the technique has been extensively used to highlight chromosomal aberrations in both hematological and solid malignancies. The introduction of this technique to clinical research of malignancies has led to the identification of novel recurrent aberrations and the characterization of highly unstable chromosomes that were otherwise difficult to visualize. These findings are of vital influence to diagnosis, therapy and further research.

Perhaps, one of the challenges of SKY detection of intrachromosomal arrangements, has been remedied with the introduction of

\section{REFERENCES}

1. Harper PS. The discovery of the human chromosome number in Lund, 1955-1956. Hum Genet. 2006; 119(12): 226-232.

2. Imataka G, Arisaka O. Chromosome Analysis Using Spectral Karyotyping (SKY). Cell Biochem Biophys. 2012; 62(1): 13-7. doi: 10.1007/s12013-011-9285-2.

3. Lejeune J, Turpin R, Gautier M. Mongolism; a chromosomal disease (trisomy). Bull Acad Natl Med. 1959; 143(11-12): 256-65.

4. Imataka $\mathrm{G}$, Mitsui $\mathrm{M}$, Mitsui $\mathrm{N}$, Hirabayashi $\mathrm{H}$, Yamanouchi H, Eguchi M. Down syndrome with acute epiglottitis. Pediatrics International. 2005; 47: 333-335.

5. Edwards JH, Harnden DG, Cameron AH, Crosse VM, Wolff OH. A new trisomic syndrome. Lancet.1960; 11(7128): 787-790.

6. Imataka G, Nitta A, Suzumura H, Watanabe H, Yamanouchi H, Arisaka O. Survival of trisomy 18 cases in Japan. Genetic Counseling. 2007; 18(3): 303-308.

7. Patau K, Smith DW, Therman E, Inhorn SL, Wagner HP. Multiple congenital anomaly caused by an extra autosome. Lancet. 1960; 1(7128): 790-3.

8. de Grouchy J, Turleau C, Leonard C. Study by fluorescence of a trisomy $C$ mosaic, probably 8: 46, XY47, XY,? 8?. Annales de Genetique.1971; 14(1): 69-72.

9. Iselius L, Lindsten J, Aurias A, Fraccaro M, Bastard $\mathrm{C}$, et al. The 11q;22q translocation: A collaborative study of 20 new cases and analysis of 110 families. Human Genetics. 1983; 64(4): 343-355.

10. Imataka G, Takaya Y, Hagisawa S, Yamanouchi H, Eguchi M. Trisomy 11/22 diagnosed by spectral karyotyping (SKY). Genetic Counseling. 2004; 15(3): 391-394.
mCMB and SCAN. These techniques follow the principle of SKY and analyze every single chromosome in a genome, thus allowing simultaneous visualization of chromosome bands in different colors in a single

hybridization. Therefore, if SKY analyzes a whole karyotype in different colors, SCAN and $\mathrm{mCMB}$ with SKY analyze each single chromosome in a genome highlighting the bands in different colors. A combination of SKY and SCAN or mCMB can serve as a very powerful cytogenetic tool.

\section{ACKNOWLEDGMENTS}

I thank the Department of Medical Laboratory Sciences, Faculty of Allied Health Sciences, Bayero University, Kano and Department of Medical Laboratory Science, Faculty of Allied Health Science, Ahmadu Bello University, Zaria for their constant support.

\section{CONFLICT OF INTEREST}

The author declares no conflict of interest.

11. Ford CE, Jones KW, Polani PE, De Almeida JC, Briggs JH. A sex-chromosome anomaly in a case of gonadal dysgenesis (Turner's syndrome). Lancet. 1959; 1(7075): 711-713

12. Tanner JM, Prader A, Habich H, Ferguson-Smith MA. Genes on the $Y$ chromosome influencing rate of maturation in man: Skeletal age studies in children with Klinefelter's $(X X Y)$ and Turner's (XO) syndromes. Lancet. 1959; 2(7095): 141-144.

13. Yamanouchi H, Imataka G, Nakagawa E, Nitta A, Suzuki N, Hirao J, et al. An analysis of epilepsy with chromosomal abnormalities. Brain Dev. 2005; 27(5): 370-377.

14. Caspersson T, Castleman KR, Lomakka G, Modest EJ, Moller A, Nathan R, et al. Automatic karyotyping of quinacrine mustard stained human chromosomes. Experimental Cell Research. 1971; 67(1): 233-235.

15. Yunis JJ, Chandler ME. High-resolution chromosome analysis in clinical medicine. Progress in Clinical Pathology. 1978; 7: 267-288.

16. Trask BJ. Fluorescence in situ hybridization: Applications in cytogenetics and gene mapping. Trends in Genetics. 1991; 7(5): 149-154.

17. Kallioniemi A, Kallioniemi OP, Sudar D, Rutovitz D, Gray JW, Waldman F, et al. Comparative genomic hybridization for molecular cytogenetic analysis of solid tumors. Science. 1992; 258(5083): 818-821.

18. Schröck E, du Manoir S, Veldman T, Schoell B, Wienberg J, Ferguson-Smith MA, et al. Multicolor spectral karyotyping of human chromosomes. Science. 1996; 273 (5274): 494-497. 
19. Boveri T. Concerning the origin of malignant tumours by Theodor Boveri. Journal of Cell Science. 2008; 121(Suppl 1): 1-84. doi: 10.1242/jcs.025742.

20. Macconaill LE, Garraway LA. Clinical implications of the cancer genome. J Clin Oncol. 2010; 28(35): 521928. doi: 10.1200/JCO.2009.27.4944.

21. Garraway LA, Lander ES. Lessons from the Cancer Genome. Cell. 2013; 153(1): 17-37. doi: 10.1016/j.cell.2013.03.002.

22. International Human Genome Sequencing Consortium. Finishing the euchromatic sequence of the human genome. Nature. 2004; 431(7011): 931-945.

23. Davies H, Bignell GR, Cox C, Stephens P, Edkins S, Clegg S, et al. Mutations of the BRAF gene in human cancer. Nature. 2004; 431(7011): 931-45.

24. Samuels Y, Wang Z, Bardelli A, Silliman N, Ptak J, Szabo $\mathrm{S}$, et al. High frequency of mutations of the PIK3CA gene in human cancers. Science. 2004; 304(5670): 554.

25. Pao W, Miller V, Zakowski M, Doherty J, Politi K, Sarkaria I, et al. EGF receptor gene mutations are common in lung cancers from "never smokers" and are associated with sensitivity of tumors to gefitinib and erlotinib. Proc Natl Acad Sci USA. 2004; 101(36): 13306-11.

26. Hudson TJ, Anderson W, Artez A, Barker AD, Bell $\mathrm{C}$, Bernabe RR, et al. International Cancer Genome Consortium. International network of cancer genome projects. Nature. 2010; 464: 993-998.

27. Garini Y, Macvillez M, du Manoir S, Buckwald RA, Lavi M, Katzir N, et al. Spectral Karyotyping. Bioimaging. 1996; 4: 65-72.

28. Trakhtenbrot L. Spectral Karyotyping. In: Schwab M. (eds) Encyclopaedia of Cancer. Springer, Berlin, Heidelberg. 2011.

29. Macville M, Veldman T, Padilla-Nash H, Wangsa D, O'Brien P, Schröck E, et al. Spectral karyotyping, a 24colour FISH technique for the identification of chromosomal rearrangements. Histochem Cell Biol. 1997; 108(4-5): 299-305.

30. Macville M, Schröck E, Padilla-Nash H, Keck C, Ghadimi BM, Zimonjic D, et al. Comprehensive and definitive molecular cytogenetic characterization of HeLa cells by spectral karyotyping. Cancer research. 1999; 59(1): 141-50.

31. Pan Y, Kytölä S, Farnebo F, Wang N, Lui WO, Nupponen N, et al. Characterization of chromosomal abnormalities in prostate cancer cell lines by spectral karyotyping. Cytogenetic and Genome Research. 1999; 87(3-4): 225-32.

32. Zhang FF, Murata-Collins JL, Gaytan P, Forman SJ, Kopecky KJ, Willman CL, et al. Twenty-four-color spectral karyotyping reveals chromosome aberrations in cytogenetically normal acute myeloid leukemia. Genes, Chromosomes and Cancer. 2000; 28(3): 318-28.

33. Melcher R, Steinlein C, Feichtinger W, Müller CR, Menzel T, Lührs H, et al. Spectral karyotyping of the human colon cancer cell lines SW480 and SW620. Cytogenetic and Genome Research. 2000; 88(1-2): 14552.

34. Van den Bos H. Aneuploidy in the Human Brain and Cancer: Studying Heterogeneity Using Single-cell Sequencing. University of Groningen. 2017;132. (Thesis).
35. Kytölä S, Rummukainen J, Nordgren A, Karhu R, Farnebo F, Isola J, et al. Chromosomal alterations in 15 breast cancer cell lines by comparative genomic hybridization and spectral karyotyping. Genes, Chromosomes and Cancer. 2000; 28(3): 308-317.

36. Bayani J, Zielenska M, Marrano P, Ng YK, Taylor $\mathrm{MD}$, Jay V, et al. Molecular cytogenetic analysis of medulloblastomas and supratentorial primitive neuroectodermal tumors by using conventional banding, comparative genomic hybridization, and spectral karyotyping. Journal of neurosurgery. 2000; 93(3): 43748.

37. Nordgren A, Sørensen AG, Tinggaard-Pedersen NI, Blennow EL, Larsson CA, Lagercrantz S. New chromosomal breakpoints in non-Hodgkin's lymphomas revealed by spectral karyotyping and G-banding. Int $\mathrm{J}$ Mol Med. 2000; 5(5): 485-92.

38. Adeyinka A, Kytola S, Mertens F, Pandis N, Larsson C. Spectral karyotyping and chromosome banding studies of primary breast carcinomas and their lymph node metastases. Int J Mol Med. 2000; 5(3): 235-40.

39. Fadl-elmula I, Kytölä S, Pan Y, Lui WO, Derienzo G, Forsberg L, et al. Characterization of chromosomal abnormalities in uroepithelial carcinomas by $G$-banding, spectral karyotyping and FISH analysis. Int $\mathrm{J}$ Cancer. 2001; 92(6): 824-31.

40. Sawyer JR, Lukacs JL, Thomas EL, Swanson CM, Goosen LS, Sammartino G, et al. Multicolour spectral karyotyping identifies new translocations and a recurring pathway for chromosome loss in multiple myeloma. Br J Haematol. 2001; 112(1): 167-74.

41. Rummukainen J, Kytölä S, Karhu R, Farnebo F, Larsson C, Isola JJ. Aberrations of chromosome 8 in 16 breast cancer cell lines by comparative genomic hybridization, fluorescence in situ hybridization, and spectral karyotyping. Cancer Genetics. 2001; 126(1): 17.

42. Beheshti B, Park PC, Sweet JM, Trachtenberg J, Jewett MA, Squire JA. Evidence of chromosomal instability in prostate cancer determined by spectral karyotyping (SKY) and interphase fish analysis. Neoplasia. 2001; 3(1): 62-9.

43. Abdel-Rahman WM, Katsura K, Rens W, Gorman PA, Sheer D, Bicknell D, et al. Spectral karyotyping suggests additional subsets of colorectal cancers characterized by pattern of chromosome rearrangement. Proceedings of the National Academy of Sciences. 2001; 98(5): 2538-43.

44. Sirivatanauksorn V, Sirivatanauksorn Y, Gorman PA, Davidson JM, Sheer D, Moore PS, et al. Non-random chromosomal rearrangements in pancreatic cancer cell lines identified by spectral karyotyping. Int J Cancer. 2001; 91(3): 350-8.

45. Harding MA, Arden KC, Gildea JW, Gildea JJ, Perlman EJ, Viars C, et al. Functional genomic comparison of lineage-related human bladder cancer cell lines with differing tumorigenic and metastatic potentials by spectral karyotyping, comparative genomic hybridization, and a novel method of positional expression profiling. Cancer research. 2002; 62(23): 6981-9. 
46. Roschke AV, Stover K, Tonon G, Schäffer AA, Kirsch IR. Stable karyotypes in epithelial cancer cell lines despite high rates of ongoing structural and numerical chromosomal instability. Neoplasia. 2002; 4(1): 19-31.

47. Mrózek K, Heinonen K, Theil KS, Bloomfield CD. Spectral karyotyping in patients with acute myeloid leukemia and a complex karyotype shows hidden aberrations, including recurrent overrepresentation of $21 q, 11 q$, and $22 q$. Genes, Chromosomes and Cancer. 2002; 34(2): 137-53

48. Squire JA, Bayani J, Luk C, Unwin L, Tokunaga J, MacMillan C, et al. Molecular cytogenetic analysis of head and neck squamous cell carcinoma: by comparative genomic hybridization, spectral karyotyping, and expression array analysis. Head neck. 2002; 24(9): 87487.

49. Rao PH, Harris CP, Yan Lu X, Li N, Mok SC, Lau CC. Multicolor spectral karyotyping of serous ovarian adenocarcinoma. Genes, Chromosomes and Cancer. 2002; 33(2): 123-32.

50. Wong N, Hui AB, Fan B, Lo KW, Pang E, Leung SF, et al. Molecular cytogenetic characterization of nasopharyngeal carcinoma cell lines and xenografts by comparative genomic hybridization and spectral karyotyping. Cancer genetics and cytogenetics. 2003; 140(2): 124-32.

51. Bayani J, Zielenska M, Pandita A, Al-Romaih K, Karaskova J, Harrison K, et al. Spectral karyotyping identifies recurrent complex rearrangements of chromosomes 8,17 , and 20 in osteosarcomas. Genes, Chromosomes and Cancer. 2003; 36(1): 7-16.

52. Harris CP, Lu XY, Narayan G, Singh B, Murty VV, Rao PH. Comprehensive molecular cytogenetic characterization of cervical cancer cell lines. Genes, Chromosomes and Cancer. 2003; 36(3): 233-41.

53. Grigorova M, Lyman RC, Caldas C, Edwards PA. Chromosome abnormalities in 10 lung cancer cell lines of the NCI-H series analyzed with spectral karyotyping. Cancer Genetics. 2005; 162(1): 1-9.

54. Prowald A, Wemmert S, Biehl C, Storck S, Martin T, Henn $\mathrm{W}$, et al. Interstitial loss and gain of sequences on chromosome 22 in meningiomas with normal karyotype. Int J Oncol. 2005; 26(2): 385-93.

55. Yamashita $\mathrm{Y}$, Nishida K, Okuda T, Nomura K, Matsumoto Y, Mitsufuji S, et al. Recurrent chromosomal rearrangements at bands $8 q 24$ and $11 q 13$ in gastric cancer as detected by multicolor spectral karyotyping. World journal of gastroenterology: WJG. 2005; 11(33): 5129 .

56. Karpova MB, Schoumans J, Blennow E, Ernberg I, Henter JI, Smirnov AF, et al. Combined spectral karyotyping, comparative genomic hybridization, and in vitro apoptyping of a panel of Burkitt's lymphomaderived $B$ cell lines reveals an unexpected complexity of chromosomal aberrations and a recurrence of specific abnormalities in chemoresistant cell lines. Int $\mathrm{J}$ Oncol. 2006; 28(3): 605-17.

57. Uchida K, Oga A, Okafuji M, Mihara M, Kawauchi S, Furuya T, et al. Molecular cytogenetic analysis of oral squamous cell carcinomas by comparative genomic hybridization, spectral karyotyping, and fluorescence in situ hybridization. Cancer Genet Cytogenet. 2006; 167(2): 109-16.
58. Duelli DM, Padilla-Nash HM, Berman D, Murphy KM, Ried T, Lazebnik Y. A virus causes cancer by inducing massive chromosomal instability through cell fusion. Current Biology. 2007; 17(5): 431-7.

59. Melcher R, Al-Taie O, Kudlich T, Hartmann E, Maisch S, Steinlein C, et al. SNP-Array genotyping and spectral karyotyping reveal uniparental disomy as early mutational event in MSS-and MSI-colorectal cancer cell lines. Cytogenet Genome Res. 2007; 118(2-4):214-21.

60. Varella-Garcia M, Chen L, Powell RL, Hirsch FR, Kennedy TC, Keith R, et al. Spectral karyotyping detects chromosome damage in bronchial cells of smokers and patients with cancer. Am J Respir Crit Care Med. 2007; 176(5): 505-12.

61. Salido M, Arriola E, Carracedo A, Cañadas I, Rovira $\mathrm{A}$, Espinet B, et al. Cytogenetic characterization of NCIH69 and NCI-H69AR small cell lung cancer cell lines by spectral karyotyping. Cancer Genetics. 2009; 191(2): 97101. doi: 10.1016/j.cancergencyto.2009.01.016.

62. Stephens PJ, Greenman CD, Fu B, Yang F, Bignell $\mathrm{GR}$, Mudie LJ, et al. Massive genomic rearrangement acquired in a single catastrophic event during cancer development. Cell. 2011; 144(1): 27-40. doi: 10.1016/j.cell.2010.11.055.

63. Koch A, Hatina J, Rieder H, Seifert HH, Huckenbeck W, Jankowiak F, et al. Discovery of TP53 splice variants in two novel papillary urothelial cancer cell lines. Cellular Oncology. 2012; 35(4):243-57. doi: 10.1007/s13402-012-0082-8.

64. Ling H, Spizzo R, Atlasi Y, Nicoloso M, Shimizu M, Redis RS, et al. CCAT2, a novel noncoding RNA mapping to $8 q 24$, underlies metastatic progression and chromosomal instability in colon cancer. Genome Res. 2013; 23(9): 1446-61. doi: 10.1101/gr.152942.112.

65. Das K, Gunasegaran B, Tan IB, Deng N, Lim KH, Tan P. Mutually exclusive FGFR2, HER2, and KRAS gene amplifications in gastric cancer revealed by multicolour FISH. Cancer letters. 2014; 353(2):167-75. doi: 10.1016/j.canlet.2014.07.021.

66. Baykara O, Bakir B, Buyru N, Kaynak K, Dalay N. Amplification of chromosome 8 genes in lung cancer. $\mathrm{J}$ Cancer. 2015; 6(3): 270-5. doi: 10.7150/jca.10638.

67. Sorber R, Teper Y, Abisoye-Ogunniyan A, Waterfall $\mathrm{JJ}$, Davis S, Killian JK, et al. Whole genome sequencing of newly established pancreatic cancer lines identifies novel somatic mutation (c. 2587G>A) in axon guidance receptor plexin $A l$ as enhancer of proliferation and invasion. PLoS One. 2016; 11(3): e0149833. doi: 10.1371/journal.pone.0149833.

68. Singchat W, Hitakomate E, Rerkarmnuaychoke B, Suntronpong A, Fu B, Bodhisuwan W, et al. Genomic alteration in head and neck squamous cell carcinoma (HNSCC) cell lines inferred from karyotyping, molecular cytogenetics, and Array comparative genomic hybridization. PLoS One. 2016; 11(8): e0160901. doi: 10.1371/journal.pone.0160901.

69. Sun Y, Ji P, Chen T, Zhou X, Yang D, Guo Y, et al. MIIP haploinsufficiency induces chromosomal instability and promotes tumour progression in colorectal cancer. $\mathrm{J}$ Pathol. 2017; 241(1): 67-79. doi: 10.1002/path.4823. 
70. El-Zein RA, Abdel-Rahman S, Santee KJ, Yu R, Shete S. Identification of small and non-small cell lung cancer markers in peripheral blood using cytokinesisblocked micronucleus and spectral karyotyping assays. Cytogenet Genome Res. 2017; 152(3): 122-131. doi: $10.1159 / 000479809$.

71. Wangsa D, Braun R, Schiefer M, Gertz EM, Bronder $\mathrm{D}$, Quintanilla $\mathrm{I}$, et al. The evolution of single cellderived colorectal cancer cell lines is dominated by the continued selection of tumor-specific genomic imbalances, despite random chromosomal instability. Carcinogenesis. 2018; doi: 10.1093/carcin/bgy068.

72. Zhou B, Ho SS, Greer SU, Spies N, Bell JM, Zhang $\mathrm{X}$, et al. Haplotype-resolved and integrated genome analysis of the cancer cell line HepG2. Nucleic Acids Res. 2019; 47(8): 3846-3861. doi: 10.1093/nar/gkz169.

73. Mrózek K, Eisfeld AK, Kohlschmidt J, Carroll AJ, Walker CJ, Nicolet D, et al. Complex karyotype in de novo acute myeloid leukemia: typical and atypical subtypes differ molecularly and clinically. Leukemia. 2019; 33(7): 1620-1634. doi: 10.1038/s41375-019-03903.
74. Kuźniacka A, Mertens F, Strömbeck B, Wiegant J, Mandahl N. Combined binary ratio labeling fluorescence in situ hybridization analysis of chordoma. Cancer Genet. Cytogenet. 2004; 151(2): 178-81.

75. Szuhai K, Tanke HJ. COBRA : combined binary ratio labeling of nucleic- acid probes for multi-color fluorescence in situ hybridization karyotyping. Nat. Protoc. 2006; 1(1): 264-275.

76. Vorsanova SG, Yurov YB Iourov IY. Human interphase chromosomes: a review of available molecular cytogenetic technologies. Mol Cytogenet. 2010; 3: 1. doi: 10.1186/1755-8166-3-1.

77. Kakazu N, Abe T. Multicolor banding technique, spectral color banding (SCAN): new development and applications. Cytogenetic and genome research. 2006; 114(3-4): 250-6. 